\title{
Analisis Kesulitan Guru dan Siswa pada Materi Statistika di SMA Advent Purwodadi
}

\author{
Mega Suliani ${ }^{*}$, Rinda Azmi Saputri ${ }^{2}$ \\ ${ }^{1}$ Pendidikan Matematika, Pascasarjana, Universitas Negeri Surabaya, Surabaya \\ 2 Pendidikan Matematika, FKIP, Universitas Islam Negeri Antasari Banjarmasin, Banjarmasin \\ *email: megasuliani94@gmail.com
}

\begin{abstract}
This study aims to analyze the difficulties experienced by students and teachers, especially in statistical materials and offered alternative solutions. The method used in this study used a qualitative approach with a descriptive type. The subjects in this study were 32 students of class XI IPA and a mathematics teacher at SMA ADVENT Purwodadi Malang. The results showed that the teacher had difficulty explaining the statistical material in group data. The difficulties faced by the teacher were caused by students who had difficulty in applying the group data formula. The difficulties faced by students vary, including understanding concepts (misconceptions), formulation (error in principle), modeling (fact errors), and calculation operations (operating errors). The difficulties experienced by the students resulted in the difficulty level of the questions. The problems given fall into the medium and easy criteria. An alternative solution is offered, that is, when learning for statistics material, it can use a problem-based learning model.
\end{abstract}

Keywords: Difficulty; Statistics; Problem Solving; Solutions; Problem-Based Learning

\begin{abstract}
Abstrak
Penelitian ini bertujuan untuk menganalisis kesulitan yang dialami peserta didik dan guru khususnya pada materi statistika serta solusi alternative yang ditawarkan. Metode yang digunakan dalam penelitian ini menggunakan pendekatan kualitatif dengan jenis deskriptif. Subjek dalam penelitian ini yaitu Peserta didik kelas XI IPA dengan jumlah 32 peserta didik dan seorang guru matematika di SMA ADVENT Purwodadi Malang. Hasil Penelitian menunjukan bahwa guru mengalami kesulitan saat menjelaskan materi statistika pada data kelompok. Kesulitan yang dihadapi guru disebabkan oleh peserta didik yang kesulitan pada penerapan rumus data kelompok. Kesulitan yang dihadapi Peserta didik beragam diantaranya pemahaman konsep (kesalahan konsep), perumusan (kesalahan prinsip), pemodelan (kesalahan fakta), serta oprasi hitung (kesalahan operasi). Kesulitan yang dialami oleh perseta didik berakibatkan pada tingkat kesukaran soal. Persoalan yang diberikan masuk pada kriteria sedang dan mudah. Solusi alternative yang ditawarkan yaitu pada saat pembelajaran untuk materi statistika dapat menggunaan model pembelajaran berbasis masalah.
\end{abstract}

Kata Kunci: Kesulitan; Statistika; Pemecahan Masalah; Solusi; Pembelajaran Berbasis Masalah.

\section{PENDAhUlUAN}

Pendidik dituntut untuk selalu meningkatkan diri baik dalam pengetahuan matematika maupun pengelolaan proses belajar mengajar. Hal ini dalam upaya untuk meningkatkan mutu pendidikan khususnya mata pelajaran matematika. Ini dimaksudkan agar para peserta didik dapat mempelajari matematika dengan baik dan benar sehingga mereka mampu mengikuti perkembangan ilmu pengetahuan dan teknologi serta dapat menerapkannya dalam kehidupan sehari-hari. 


\section{Mandalika Mathematics and Education Journal \\ Volume 3 Nomor 1, Juni 2021 \\ e-ISSN 2715-1190| | p-ISSN 2715-8292 \\ DOI: http://dx.doi.org/10.29303/jm.v3i1.2673}

Keanekaragaman kemampuan intelektual peserta didik khususnya dalam matematika di SMA sangat bervariasi. Kemampuan ini menyangkut kemampuan untuk: mengingat kembali, memahami, menginterpretasi informasi, memahami makna simbol dan memanipulasinya, mengabstraksi, menggeneralisasi, menalar, memecahkan masalah, dan masih banyak lagi. Sikap dan perangai peserta didik pun beraneka ragam, baik dalam menanggapi pembelajaran pada umumnya maupun matematika pada khususnya (Gangga, 2013).

Sholekah, Anggreini, \& Waluyo (2017) berpendapat bahwa matematika merupakan salah satu mata pelajaran yang dalam proses pembelajarannya membutuhkan pemahaman yang tinggi dan bukan hanya sekedar hafalan. Matematika diperlukan oleh Peserta didik untuk memenuhi kebutuhan guna memecahkan masalah dalam kehidupan sehari-hari, seperti halnya mengoperasikan perhitungan, menentukan nilai rata-rata dari suatu kelompok, dan dalin sebagainya.

Materi statistika merupakan salah satu materi yang wajib ditempuh oleh peserta didik di sekolah. Berdasarkan hasil wawancara dengan guru mata pelajaran matematika di SMA Advent Purwodadi, menyebutkan masih ada peserta didik yang mengalami kesulitan pada materi tersebut. Ketidakberhasilan peserta didik jangan dipandang sebagai hal yang biasa saja terjadi pada pembelajaran matematika. Sedemikian hingga, ada peserta didik yang berhasil dan ada pula yang tidak. Dorongan guru untuk memecahkan masalah kesulitan peserta didik merupakan salah satu unsur dalam pengembangan profesi guru. Hal ini berlandas pada prinsip diagnosis dalam konteks pemecahan masalah.

Menurut Muhibbin (2010) Seseorang mengalami kesulitan dalam belajar biasanya tampak jelas dari menurunnya kinerja akademik atau prestasi belajarnya. Salah satu faktornya Peserta didik mengalami kesulitan dalam meerima materi pada pembelajaran matematika yaitu menurunya tingkat keberhasilan dalam pembelajaran matematika dan ketikmapuan Peserta didik dalam memecahkan masalah matematika (Sholekah, et al., 2017)

Kesulitan Peserta didik dalam menyelesaikan masalah juga dapat dilihat dari kesalahan yang timbul dalam menyelesaikan masalah yang diberikan. Seseorang mengalami kesulitan dalam proses belajar akan menunjukkan ciri-ciri dari adanya masalah yang sedang dialami, seperti yang dituliskan oleh Muhkal (dalam Rahim, 2013) sebagai berikut: (a) menunjukkan hasil belajar yang lebih rendah (dibawah nilai rata-rata) yang dicapai oleh kelompoknya; (b) hasil yang dicapai tidak seimbang dengan usaha yang dilakukannya; (c) lambat dalam melaksanakan tugas-tugas belajarnya; (d) menunjukkan sikap-sikap yang kurang wajar; (e) menunjukkan tingkah laku yang berkelainan dan; (f) menunjukkan gejala emosional yang kurang wajar. 
Terdapat empat objek dasar matematika yaitu fakta, kosep, operasi, dan prinsip. Apabila kesalahan dalam menyelesaikan masalah dihubungkan dengan objek dasar matematika, sehingga menurut Soedjadi (2000), terdapat empat jenis kesalahan jika dihubungkan dengan objek dasar matematika, yaitu: (1) Kesalahan fakta merupakan kekeliruan dalam menuliskan konvensi-konvensi yang dinyatakan dengan simbol-simbol matematika. Sebagai contoh, kesalahan dalam mengubah permasalahan ke dalam bentuk model matematika, kesalahan dalam menginterpretasikan hasil yang didapatkan dan kesalahan dalam menuliskan simbol-simbol matematika. (2) Kesalahan konsep merupakan kekeliruan dalam menggolongkan atau mengklasifikasikan sekumpulan objek. Konsep yang dimaksud dalam matematika dapat berupa definisi. Sebagai contoh, kesalahan dalam menggolongkan suatu relasi, apakah merupakan suatu fungsi atau tidak. (3) Kesalahan operasi merupakan kekeliruan dalam pengerjaan hitung, pengerjaan aljabar, dan pengerjaan matematika yang lain. Sebagai contoh, kesalahan dalam menjumlahkan, mengurangkan, dan kesalahan dalam operasi matematika lainnya. (4) Kesalahan prinsip merupakan kekeliruan dalam mengaitkan beberapa fakta atau beberapa konsep. Sebagai contoh, kesalahan dalam menggunakan rumus ataupun teorema serta kesalahan dalam menggunakan prinsip-prinsip sebelumnya.

Masalah merupakan sesuatu yang pasti ditemui dalam kehidupan yang harus dipecahkan, bukan dihindari, karena dengan menghindarinya di samping akan muncul lagi masalah yang sama atau serupa juga memmungkinkan menambah banyak masalah yang semakin sulit dipecahkan. Menurut Cruikshank \& Sheffield (1992) bahwa masalah matematika merupakan pertanyaan atau situasi yang berhubungan dengan matematika, tetapi tidak hanya terkait dengan angka. Ada kemungkinan bahwa beberapa masalah matematika melibatkan sifat penalaran logis, serta tidak berhubungan dengan angka sama sekali.

Kesulitan yang dihadapi peserta didik itu perlu ditemukan dan dipastikan sumbernya. Oleh karena itu, peneliti merumuskan masalah untuk membahas tentang kesulitan yang dialami peserta didik dan guru khususnya pada materi statistika sebagai berikut.

1. Apa saja kesulitan guru pada saat pembelajaran materi statistika di SMA Advent Purwodadi?

2. Kesulitan belajar apa yang dialami oleh peserta didik dalam pembelajaran materi statistika di SMA Advent Purwodadi?

3. Bagaimana solusi alternatif pemecahan dari diagnosis kesulitan dalam pembelajaran materi statistika di SMA Advent Purwodadi? 


\section{METODE}

Pendekatan yang digunakan dalam penelitian ini adalah pendekatan kualitatif dengan jenis penelitian deskriptif. Penelitian kualitatif berusahan untuk memahami fenomena tentang apa yang dialami oleh subjek penelitian secara holistic, dan dengan cara deskriptif dalam bentuk kata-kata dan Bahasa, pada suatu konteks khusus yang alamiah dengan memanfaatkan berbagai metode ilmiah (Moleong, 2015). Penelitian ini dimaksud untuk memperoleh informasi dan mendeskripsikan terkaiat kesuliatan yang dihadapi oleh guru dan Peserta didik dalam pembelajaran pada materi statistika serta solusi alternatifnya.

Subjek penelitian merupakan seseorang atau sesuatu yang diperlukan untuk memperoleh informasi dalam pengumpulan data penelitian (Rahardi, 2015). Subjek dalam penelitian ini adalah peserta didik kelas XI IPA dengan jumlah 32 peserta didik dan seorang guru matematika. Peserta didik kelas XI IPA dipilih berdasarkan saran dari guru matematika di SMA Advent Purwodadi, karena kelas tersebut sudah menempuh materi statistika pada semester sebelumnya. Guru juga menginformasikan bahwa peserta didik pada kelas XI IPA mempunyai kemampuan matematika yang cukup baik.

Data dikumpulkan melalui instrument yang berupa dokumen dan wawancara. Instrumen yang digunakan adalah tes kemampuan geometri terdiri dari tiga item, dan instrumen yang akan benar digunakan dalam penelitian telah memenuhi validitas dan reliabilitas. Dokumen yang digunakan dalam penelitian ini adalah hasil tes penyelesaian masalah statistika dan wawancara dilakukan oleh guru yang menjadi subjek seperti yang disebutkan di atas.

Teknik analisis data dalam penelitian ini yaitu reduksi data, menyajikan data, dan penarikan kesimpulan. Reduksi data dilakukan dengan tujuan memilih data yang nantinya dapat dianalisis dan mendukung penelitian dengan data yang tidak diperlukan. Setelah data sudah terkumpul, selanjutnya data tersebut disajikan dalam bentuk deskriptif dan akan disajikan menjadi sebuah kesimpulan dari hasil penelitian yang sudah diperoleh.

\section{HASIL DAN PEMBAHASAN}

\subsection{Hasil}

Tujuan dari penelitian ini adalah menganalisis kesulitan yang dialami peserta didik dan guru khususnya pada materi statistika serta solusi alternative yang ditawarkan. Menurut hasil wawancara, adapun kesulitan yang dialami guru pada saat pembelajaran khususnya materi statistika yaitu ketika guru menjelaskan materi rata-rata, median, 
modus data kelompok. Karena Peserta didik kesulitan pada saat menerapan rumus data kelompok.

Guru dalam proses pembelajaran menggunakan metode pembelajaran diskusi dan LKS. Materi statistika sudah ditempuh sejak di bangku SMP, namun siwa masih mengalami kesulitan dalam menggunakan penerapan pada data kelompok. Setelah memahami konsep peserta didik diarahkan untuk berdiskusi dengan kelompok dengan bantuan LKS. Metode diskusi dibantu dengan pengerjaan LKS yang telah disediakan, dimana peserta didik dibimbing untuk memahami konsep dari statistika.

Jika ada peserta didik yang mengalami kesulitan dalam kelompok, maka peserta didik lainnya yang sudah paham bisa mengajari peserta didik yang mengalami kesulitan. Jika teman sebayanya tidak ada yang bisa menyelesaikan persoalan yang diberikan, maka guru membimbing langsung peserta didik tersebut. Guru menyimpulkan materi yang telah dipelajari di akhir pembelajaran. Sedangkan kesulitan yang dialami peserta didik berdasarkan hasil wawancara dengan guru matematika yaitu peserta didik kesulitan dalam data kelompok, baik menentukan modus, median, rata-rata.

Berdasarkan hasil penelitian dari 32 peserta didik diperolah data 29 peserta didik yang mampu menyelesaikan persoalan yang telah diberikan. Adapun persoalan tersebut terdiri dari 3 (tiga) permasalahan. Permasalahan pertama yaitu peserta didik diminta menjelaskan pengertian rata-rata, median, modus. Permasalahan kedua yaitu peserta didik diminta menuliskan aturan yang digunakan untuk merumuskan rata-rata, median, dan modus. Permasalahan ketiga yaitu menghitung rata-rata, median, modus. Hasil yang diperoleh untuk permasalahan pertama yaitu 29 peserta didik tidak dapat menjelaskan pengertian rata-rata dan 26 peserta didik tidak dapat menjelaskan pengertian median. Gambar 1 merupakan salah satu contoh peserta didik yang tidak bisa menjelaskan pengertian rata-rata dan median.

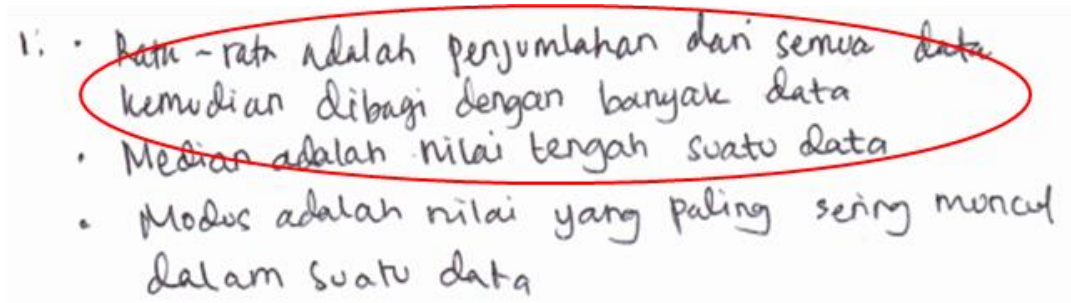

Gambar 1. Salah satu contoh peserta didik yang tidak bisa menjelaskan pengertian rata-rata

Peserta didik pada persoalan pertama sudah bisa menjelaskan pengertian modus, namun belum memahami pengertian dari rata-rata dan median. Peserta didik memahami pengertian rata-rata dari rumus rata-rata, tanpa memahami maksud rata- 
rata yaitu nilai yang dapat mewakili suatu populasi. Selain itu, peserta didik juga memahami pengertian median yaitu nilai tengah suatu data, belum memahami jika median yaitu nilai tengah dari suatu data setelah diurutkan dari yang terkecil ke yang terbesar. Pada permasalahan pertama ini peserta didik mengalami salah konsep. Seperti halnya pada Gambar 1 peserta didik menuliskan pengertian rata-rata dan median berdasarkan rumus yang diketahuinya.

Permasalahan kedua yaitu 7 (tujuh) peserta didik yang mengalami salah konsep ketika diminta menuliskan aturan yang digunakan untuk merumuskan rata-rata, median, dan modus. Adapun yang mengalami salah konsep merumuskan median saja ada 4 (empat) peserta didik, salah konsep merumuskan median dan modus ada 1 (satu) peserta didik, sedangkan salah konsep merumuskan median, rata-rata dan modus ada 2 (dua) peserta didik. 22 peserta didik lainnya sudah bisa menuliskan aturan yang digunakan untuk merumuskan rata-rata, median, dan modus. Gambar 2 merupakan salah satu contoh pengerjaan peserta didik terkait dengan permasalahan kedua, mampu merumuskan rata-rata namun tidak bisa merumuskan median dan modus.

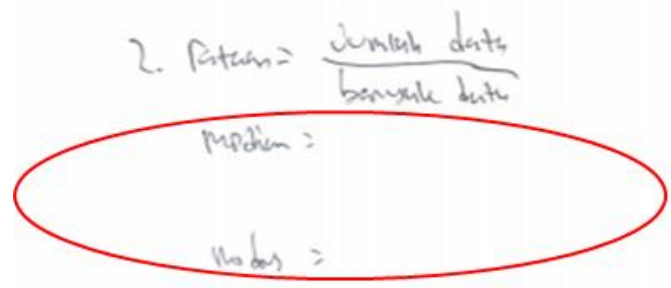

Gambar 2. Salah satu contoh pengerjaan peserta didik terkait dengan persoalan kedua.

Permasalahan ketiga yaitu tidak semua perserta didik mampu menghitung rata-rata, median, dan modus dari data yang diberikan. Adapun permasalahan ketiga ini yaitu peserta didik ada yang mengalami salah prinsip, salah konsep, salah fakta dan operasi. Ada 2 (dua) peserta didik mengalami salah operasi rata-rata, 7 (tujuh) peserta didik mengalami salah konsep median, dan 3 (tiga) peserta didik mengalami salah konsep, prinsip, operasi dan fakta pada rata-rata dan median. Sedangkan 17 peserta didik lainnya sudah bisa menghitung rata-rata, median dan modus. Gambar 3 merupakan salah satu contoh hasil pengerjaan peserta didik untuk permasalahan ketiga.

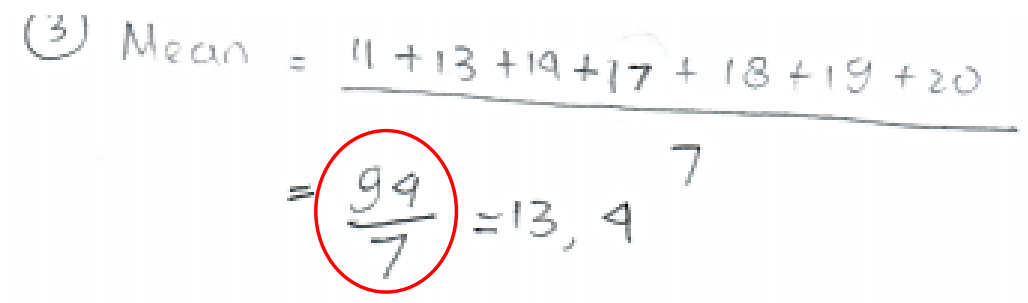


(a) Salah satu contoh hasil pengerjaan peserta didik salah operasi

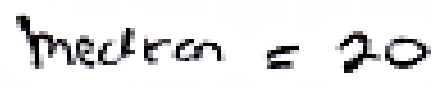

(b) Salah satu contoh hasil pengerjaan peserta didik salah konsep

Gambar 3. Salah satu contoh hasil pengerjaan peserta didik untuk permasalahan ketiga

Berdasarkan pada Gambar 3 (a) peserta didik mengalami salah operasi, di mana peserta didik salah menjumlahkan data yang diketahui. Gambar 3 (b) peserta didik mengalami salah konsep, di mana peserta didik tidak memahami median merupakan data yang terletak di tengah setelah data diurutkan dari yang terkecil ke yang terbesar. Sedangkan peserta didik yang tidak menjawab dianggap mengalami salah konsep, prinsip, fakta dan operasi.

Peserta didik yang mengalami kesulitan pada setiap persoalan dapat dilihat pada Diagram 1 sebagai berikut.

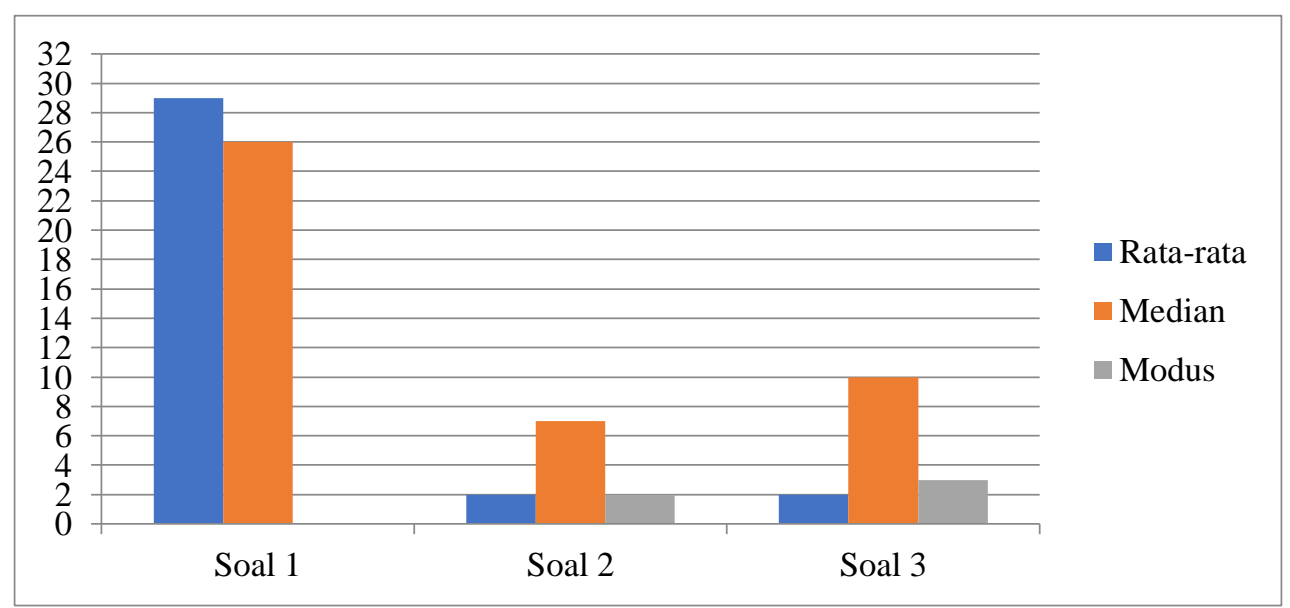

Diagram 1. Jumlah peserta didik yang mengalami kesulitan

Kesulitan yang dialami oleh peserta didik pada saat menyelesaikan permasalahan yang diberikan, berhubungan dengan tingkat kesukarang soal. Menurut Arikunto (2010), tingkat kesukaran soal dapat diukur dari jumlah peserta didik yang menjawab dengan benar. Adapun rumus perhitungan tingkat kesukaran yaitu:

$$
P=\frac{B S}{J S}
$$

dimana:

$P$ adalah indeks kesukaran, 
$B S$ adalah banyaknya peserta didik yang menjawab dengan benar, $B J$ adalah jumlah Peserta didik.

Tabel 1. Kriteria tingkat kesukaran soal

\begin{tabular}{cc}
\hline Indeks kesukaran $(\boldsymbol{P})$ & Kriteria \\
\hline $0,00 \leq P<0,30$ & Sukar \\
$0,30 \leq P<0,70$ & Sedang \\
$0,70 \leq P \leq 1$ & Mudah \\
\hline
\end{tabular}

Tingkat kesukaran permasalahan pertama pada rata-rata $=\frac{0}{29}=0$ termasuk kriteria sukar, pada median $=\frac{3}{29}=0,10$ termasuk kriteria sukar, pada modus $=\frac{29}{29}=1$ termasuk kriteria mudah, adapun rata-rata dari tingkat kesukaran permasalahan pertama = $\frac{0+0,10+1}{3}=0,37$ termasuk kriteria sedang.

Tingkat kesukaran permasalahan kedua pada rata-rata $=\frac{27}{29}=0,93$ termasuk kriteria mudah, pada median $=\frac{22}{29}=0,76$ termasuk kriteria mudah, pada modus $=\frac{27}{29}=0,93$ termasuk kriteria mudah, adapun rata-rata dari tingkat kesukaran permasalahan kedua $=\frac{0,93+0,76+0,93}{3}=0,87$ termasuk kriteria mudah.

Tingkat kesukaran permasalah ketiga pada rata-rata $=\frac{27}{29}=0,93$ termasuk kriteria mudah, pada median $=\frac{22}{29}=0,76$ termasuk kriteria mudah, pada modus $=\frac{27}{29}=0,93$ termasuk kriteria mudah, adapun rata-rata dari tingkat kesukaran permasalahan ketiga $=\frac{0,93+0,76+0,93}{29}=0,87$ termasuk kriteria mudah.

\subsection{Pembahasan}

Berdasarkan hasil jawaban ke 29 peserta didik, tidak ada yang mampu menyelesaikan semua persoalan dengan benar. Permasalahan pertama yaitu peserta didik diminta menjelaskan pengertian rata-rata, median, modus. Permasalahan kedua yaitu peserta didik diminta menuliskan aturan yang digunakan untuk merumuskan rata-rata, median, dan modus. Permasalahan ketiga yaitu menghitung rata-rata, median, modus.

Pada dasarnya peserta didik sudah memahami materi statistika, akan tetapi ada beberapa peserta didik pada saat menyelesaian masalah yang diberikan cenderung kurang teliti pada saat memahami dan menyelesaikannya. Hal ini sejalan dengan hasil penelitian Phonapichat, Wongwanich, \& Sujiva (2014) menyatakan bahwa Peserta didik mengalami kesulitan dalam memahami kata kunci yang ada dalam soal, 
Peserta didik tidak dapat menentukan apa yang harus diasumsikan dan informasi apa dari masalah yang diperlukan untuk menyelesaikan. Sehingga hal ini perlu diberi perhatian dan peringatan pada saat menyelesaikan persoalan yang lainnya, sehingga Peserta didik tidak mengulangi kesalahan yang telah dilakukan sebelumnya. Guru pada proses pembelajaran hendaknya membimbing dan memperhatikan kinerja dari peserta didik, sehingga peserta didik tidak mengalami kesalahan pada saat menyelesaikan persoalan yang diberikan. Phonapichat, Wongwanich, \& Sujiva (2014) juga mengemukaan dari hasil temuannya mengarah pada penciptaan dan pengembangan tes diagnostik pemecahan masalah matematika untuk guru, dalam rangka meningkatkan keterampilan pemecahan masalah matematika Peserta didik.

Mahdayani (2014) juga mengemukakan presentasi kesulitan peserta didik pada materi statistika ditinjau dari jenis kesulitan berdasarkan langkah pemecahan masalah yang hasilnya yaitu Peserta didik kesulitan membaca 54,6\%, kesulitan pemahaman 54,6\%, kesulitan transformasi 83,5\%, kesulitan keterampilan proses 91,7\% dan kesulitan penarikan kesimpulan $91,7 \%$. Adapun dari hasil penelitian ini, peserta didik tidak hanya mengalami kesalahan konsep, tetapi juga mengalami kesalahan operasi, prinsip, dan fakta.

Hasil penelitian Dewi, Khodijah, \& Zanthy (2020) menyatakan bahwa kesulitan peserta didik dalam menyelesaikan soal statistic berada pada indikator menentukan nilai ratarata dari suatu data dengan presentase kesalahan $80 \%$ dan pada indikator menganalisis suatu data dengan presentase kesalahan $83 \%$ yang termasuk kategori tinggi. Faktor penyebabnya adalah Peserta didik belum mampu memahami konsep dasar statistika, mengomunikasikan permasalahn dengan cara memodelkan matematika, melakukan manipulasi statistic, dan menarik kesimpulan.

Nurbahibah (2018) menamhakan dari hasil penelitiannya yang menyatakan bahwa Peserta didik mengalami kesulitan konsep, kesulitan skill, kesulitan prinsip, kesulitan fakta, dan kesulitan masalah. Adapun faktor penyebabnya didasarkan oleh faktor internal dan eksternal (Nurbahibah, 2018).

Adapun solusi yang ditawarkan oleh peneliti yaitu dengan menggunakan model pembelajaran berbasis masalah. Berikut ini Diagram 2 yaitu alur proses Pembelajaran Berbasis Masalah yang disajikan dalam bentuk flowchart.

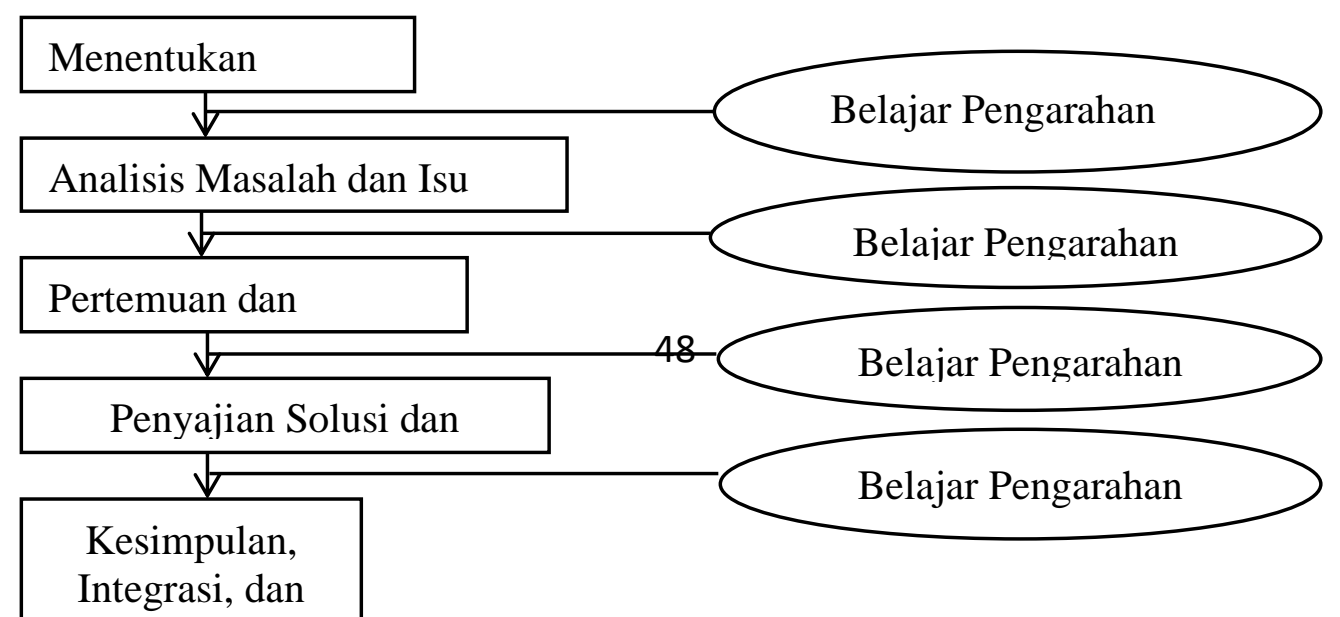




\section{Diagram 2. Keberagaman Pendekatan PBM}

Pembelajaran berbasis masalah merupakan salah satu setrategi pembelajaran yang dapat membawa peserta didik pada pembentukan kemampuan berpikir tingkat tinggi. Pendekatan ini memberikan peluang bagi peserta didik untuk melakukan penelitian dengan berbasis masalah nyata dan autentik. Langkah-langkah pembelajaran berbasis masalah yang dikemukakan oleh Ibrahim \& Nur (2000) dan Ismail (2002) sebagai berikut:

Tabel 2. Langkah-langkah pembelajaran berbasis masalah

\begin{tabular}{|c|c|c|}
\hline Fase & Indikator & Kegiatan Guru \\
\hline 1 & $\begin{array}{l}\text { Orientasi Peserta didik pada } \\
\text { masalah }\end{array}$ & $\begin{array}{l}\text { Menjelaskan tujuan pembelajaran, menjelaskan } \\
\text { logistic yang diperlukan, dan motivasi Peserta didik } \\
\text { terlibat pada aktivitas pemecahan masalah. }\end{array}$ \\
\hline 2 & $\begin{array}{l}\text { Mengorganisasi Peserta didik } \\
\text { untuk belajar }\end{array}$ & $\begin{array}{l}\text { Membantu Peserta didik mendefinisikan dan } \\
\text { mengorganisasikan tugas belajar yang berhubungan } \\
\text { dengan masalah tersebut }\end{array}$ \\
\hline 3 & $\begin{array}{l}\text { Membimbing pengalaman } \\
\text { individual/kelompok }\end{array}$ & $\begin{array}{l}\text { Mendorong Peserta didik untuk mengumpulkan } \\
\text { informasi yang sesuai, melaksanakan eksperimen } \\
\text { untuk mendapatkan penjelasan dan pemecahan } \\
\text { masalah }\end{array}$ \\
\hline 4 & $\begin{array}{l}\text { Mengembangkan dan } \\
\text { menyajikan hasil karya }\end{array}$ & $\begin{array}{l}\text { Membantu Peserta didik dalam merencanakan dan } \\
\text { menyiapkan karya yang sesuai seperti laporan, dan } \\
\text { membantu mereka untuk berbagai tugas dengan } \\
\text { temannya }\end{array}$ \\
\hline 5 & $\begin{array}{l}\text { Menganalisis dan } \\
\text { mengevaluasi proses } \\
\text { pemecahan masalah }\end{array}$ & $\begin{array}{l}\text { Membantu Peserta didik untuk melakukan refleksi } \\
\text { atau evaluasi terhadap penyelidikan mereka dan } \\
\text { proses yang mereka gunakan. }\end{array}$ \\
\hline
\end{tabular}

\section{PENUTUP}

Sejauh ini guru menggunakan metode diskusi dan kelompok. Guru mengalami kesulitan saat menjelaskan materi statistika pada data kelompok. Kesulitan yang dihadapi guru disebabkan oleh peserta didik yang kesulitan pada penerapan rumus data kelompok. Subjek penelitian ini terdiri dari 32 peserta didik, namun yang mampu menyelesaikan persoalan tersebut sebanyak 29 peserta didik. 
Berdasarkan hasil dan pembahasan diperoleh jumlah Peserta didik yang mengalami kesulitan persoalan pada rata-rata yaitu 29 peserta didik dan 26 peserta didik mengalami kesulitan pada median. Permasalahan kedua ada 2 peserta didik mengalami kesulitan aturan yang digunakan merumuskan pada rata-rata, 7 peserta didik mengalami kesulitan median, dan 2 peserta didik mengalami kesulitan modus. Permasalahan ketiga ada 2 peserta didik mengalami kesulitan menghitung rata-rata, 10 peserta didik mengalami kesulitan menghitung median, dan 3 peserta didik mengalami kesulitan menghitung modus.

Solusi yang ditawarkan yaitu penggunaan model pembelajaran berbasis masalah. Pembelajaran berbasis masalah merupakan salah satu setrategi pembelajaran yang dapat membawa Peserta didik pada pembentukan kemampuan berpikir tingkat tinggi. Pendekatan ini memberikan peluang bagi peserta didik untuk melakukan analisis dengan berbasis masalah nyata dan autentik.

Pada pembelajaran materi statistik guru disarankan menggunakan model pembelajaran berbasis masalah agar peserta didik tidak hanya sekedar tahu saja materi tersebut. Penggunaan model ini nantinya diharapkan peserta didik mampu menyelesaikan persoalan yang diberikan. Pesoalan yang nantinya diberikan bermula pada permasalahan yang berkaitan dengan kehidupan sehari-hari, sehingga pembelajaran tersebut akan bermakna.

\section{REFERENSI}

Arikunto, S. (2010). Dasar-Dasar Evaluasi Pendidikan. Jakarta: Bumi Aksara.

Crulikshank, D. E. \& Sheffeild, L. J. (1992). Teaching and learning elementary school. New York: Macmillan Publishing Company.

Dewi, D., Khodijah, S., \& Zanthy, L. (2020). Analisis Kesulitan Matematik Peserta didik SMP pada Materi Statistika. Jurnal Cendekia: Jurnal Pendidikan Matematika, 4(1), 1-7. https://doi.org/10.31004/cendekia.v4i1.148.

Gangga, U. W. A. (2013). Analisis Kesulitan Belajar Peserta didik pada Topik Limit Fungsi Aljabar dan Pemecahannya. Universitas Sebelas Maret: Surakarta.

Ibrahim, M. \& Nur, M. (2000). Pengajaran Berdasarkan Masalah. Surabaya: Unesa University Press.

Ismail. (2002). Pembelajaran Berdasarkan Masalah (problem Based Instruction): Apa Bagaimana, dan Contoh pada Subpokok Bahasa Statistika. Proseding Seminar Nasional Paradigm Baru Pembelajaran MIPA. Kerja Sama Dirjen Dikti Depdiknas dengan (JICA-IMSTEP).

Mahdayani, R. (2014). Analisis Kesulitan Peserta didik SMP dalam Pemecahan Masalah Matematika pada Materi Aritmetika, Aljabar, Statistika, dan Geometri. S2 thesis, UNY. Rusman. 2010. Model-Model Pembelajaran: Mengembangkan Profesionalisme Guru Edisi Kedua.Jakarta:Rajawali Pres.

Muhkal, M. (1998). Pengaruh Konsep Diri Matematika dan Motivasi Berprestasi Terhadap Prestasi Belajar Matematika Peserta Didik SMU Kotamadya Ujung Pandang, (Laporan Penelitian), Dirjen Dikti. 
Nina. (2014). Jenis-Jenis Kesalahan dan Menyelesaikan Soal Matematika. Artikel. https://ninamath.wordpress.com/2014/04/12/jenis-jenis-kesalahan-dalam-menyelesaikansoal-matematika/. Diakses 9 April 2016.

Nurhabibah, A. (2018). Analisis Kesulitan Peserta didik dalam Menyelesaikan Soal-soal Matematika di Kelas VII MTs.Islamiyah YPI Batang Kuis Tahun Pelajaran 2017. 2018. Skripsi thesis, Fakultas Ilmu Tarbiyah dan Keguruan.

Phonapichat, P., Wongwanich, S., \& Sujiva, S. (2014). An Analysis of Elementary School Students' Difficulties in Mathematical Problem Solving. Procedia - Social and Behavioral Sciences, 116, 3169-3174. doi:10.1016/j.sbspro.2014.01.728.

Sholekah, L. M., Anggreini, D., \& Waluyo, A. (2017). Analisis Kesulitan Peserta didik Dalam Menyelesaikan Soal Matematika Ditinjau dari Koneksi Matematika Materi Limit Fungsi. Wacana Akademika, 1(2).

Soedjadi. (2000). Kiat Pendidikan Matematika di Indonesia (Konstatasi Masa Kini Menuju Harapan Masa Depan). Jakarta: Dirjen Dikti Depdiknas. 